\title{
Feminism Criticism towards "Merariq Kodeq" Culture in West Nusa Tenggara Society
}

\author{
M Riadhussyah ${ }^{1}$, J Jumadi ${ }^{2}$, A R Subarkah ${ }^{3}$, H R Subarkah ${ }^{4}$, A S Bukhari ${ }^{5}$ \\ ${ }^{1,2}$ Universitas Mataram, ${ }^{3,4,5}$ Universitas Padjadjaran Bandung \\ ${ }^{1}$ mriadhussyah@unram.ac.id,${ }^{2}$ jokojumadi@unram.ac.id, ${ }^{3}$ alwafi17001@mail.unpad.ac.id \\ hazazi17001@mail.unpad.ac.id, ${ }^{5}$ ahmad18024@mail.unpad.ac.id
}

\begin{abstract}
This research purpose of explaining feminism criticism of merariq kodeq, which is term of the people of West Nusa Tenggara (NTB) for child marriage, Merariq in terms of the culture of the NTB society means elopement, while Kodeq means child. NTB is one of the regions with a high case of child marriage in Indonesia, and Indonesia is the highest rate of child marriage in the Southeast Asia region. Merariq Kodeq has become a culture in NTB society because it has formed a society mindset that solutions to various problems can be solved by marriage. This phenomenon threatens underage women as victims who are vulnerable to reproductive health, divorce, violence, dropping out of school, or other formal education, which ultimately results in low salary. So this study wants to see a feminist view of merariq kodek cases. This is using a qualitative method with the theory of feminism. The results of this study are feminism views that fight for equality, human rights, in this case, children's rights and women's rights must be fulfilled and protected, this view opposes the existence of merariq kodeq because it is detrimental to underage women in various aspects. Therefore, advocacy is needed in two ways, namely legal systems such as advocacy in the improvement of laws or regulations, making policies that can fulfill and protect the fundamental rights of women and children. Also, it is essential to improve the mindset in society that early marriage is not just a solution to resolving problems.
\end{abstract}

Keywords: Merariq Kodeq, Child Marriage, Feminism

\section{INTRODUCTION}

Child marriage is a global phenomenon that occurs in almost all countries in the world. Every year 12 million girls marry under the age of 18 on average 23 children get married every minute, and 1 child marries every two seconds. This phenomenon happens because of gender inequality, poverty, cultural and religious traditions, and insecurity [1]. This problem causes children (especially girls) to lose their basic rights to health, education, and safety, thus affecting their growth, stability and transformation [2]. Based on the Press Release of the Ministry of Women's Empowerment and Child Protection of the Republic of Indonesia holds the 2nd position in ASEAN and 7th in the world as the country with the highest child marriage [3]. The deputy secretary-general of ASEAN for the Social and Cultural community of Kung Phoak, said child marriage threatened the lives and future of women throughout the world. Based on data from the United Nations Population Fund (UNFPA) child marriages reached 35.4 percent 
in Laos, Indonesia accounted for 17 percent and Vietnam 11 percent [4]. While the nongovernmental organization Girls Not Bride Organization states that Indonesia is one of the countries with the eighth highest child marriage rate in the world, with a total of $1,459,000$ children who marry under the age of 18 years [5]. On average more than 3,500 Indonesian girls marry every day, and in some cases, even religious courts allow child marriages younger than 16 years [6].

The province of West Nusa Tenggara is among the top ten national child marriages, which reach 4.5 percent of married children aged 15 years, and 44 percent are under the age of 19 years [7]. There are 10 districts/cities aged 10-19 years in 2018 consisting of 30-58 percent with a distribution of 49.89 percent in West Lombok, 57.98 percent in Central Lombok, 58.05 percent in East Lombok, 47.95 percent in North Lombok, 37.81 percent in West Sumbawa, 37.32 percent in Sumbawa, 34.19 percent in Dompu, 34.64 percent in Bima, 42.14 in Mataram City, 32.95 percent in Bima City [8]. This should be a concern for all parties because of the increasing cases of child marriages in West Nusa Tenggara.

Child marriage in West Nusa Tenggara is known as "merariq Kodeq", merariq itself is a marriage bond, derived from the Sasak language, which consists of two meanings, means berari is running and other meanings of marital custom in the Sasak custom. In terms of merariq is an attempt to bring the girl running from her family with the agreement of both parties (men and women) to have a marriage, carrying this run is the first step of the act of marriage, then the next step by the parents and the bride and groom discussing related steps to prepare marriage [9]. While Kodeq which means small or child, so Merariq Kodeq means marriage which is carried out by children.

The question of this research is how does feminism view child marriage in West Nusa Tenggara? A view that upholds women's rights. This research will explain Merariq Kodeq in West Nusa Tenggara and the view of feminism. This research is important because there has not been any discussion about Merariq Kodeq, the effects that arise if that happens, the factors that influence it, and no one has seen this critique of feminism.

Some previous research on child marriage in various countries. Research from Lal about child marriage in India is rooted in religious traditions, social practices, economic factors, and prejudices that have taken root in society [10]. Then, research by Kamal shows that the education of women and their husbands, women's work, housing, and religion are important determinants of child marriages in Bangladesh [11]. Research from Wodon, Nguyen, and Tsimpo, looking at the negative impact of child marriage in Uganda, that child marriage reduces the educational attainment of girls getting married early has implications for later agency [12]. Sean Sinclair in his research in Yemen which is the cause of polio. Collaboration needs to involve all parties, ranging from the government, the community, the media to provide education and socialization regarding the dangers of child marriage in the short term and long term danger in an effort to safeguard the children's future better [13]. According to Gage's research, girls who have been married are significantly more likely to have suicidal thoughts. So, stronger community involvement is needed to prevent child marriage and mental health support for child brides [14].

\section{RESEARCH METHOD}

This research uses a qualitative method is an approach to explore and understand social problems, is child marriage [15]. This type of qualitative research is a case study, studying a problem through one or more cases in a restricted system. The case study in this research is child marriage in West Nusa Tenggara in the view of feminism. Case study research data 
collection by describing various sources of information from interviews, observations, documents, and audio-visual material [16]. Data collection in this research was carried out with a literature study on relevant and relevant documents, such as reports, books, journals, press releases, and news. The stages in this study start from data collection, data reduction, drawing conclusions and presenting narrative data.

\section{RESULT AND DISCUSSION}

The history of feminism is the movement of women who demand equal rights and justice with men. Rights correspond to human rights in the Declaration of Human Rights 1984 [17]. Mary Wollstonecraft's 1792 feminist work entitled Vindication of the rights of women states "that females are in all the most important aspects of the same as lazy, possessing the same souls, the same mental capacities, and thus the same human rights" [18]. The equality of the rights of women and men will approach the struggle as humans psychologically, spiritually and individually. He also believes that women should have the same access as men in the fields of economic and educational opportunities [17]. Women demanded to get the same lessons and methods as men. He also believes that marriages between men and women demand strata similarities in marriage, management of household resources. In the economic field, he demands the same profession and the opportunity to get a job and decent wages. Women demand representation so that they can be considered in government and policy [18].

Wollstonecraft demands a revolution in women's behavior so that equality between men and women in the household. Women assume the behavior of women who are often humble, virtuous and act on the grounds of caution and generosity, the behavior will produce tyranny between men as masters and women as slaves. He demanded to treat women with respect and act with policies and justice with rational reasons, he wanted to eliminate the superiority of men who were considered "want of chastity in men,". Wollstonecraft considers that when there is no equality it will be difficult to see women who are affectionate with the households they have built, and social life [18].

The feminism movement also demands to end sexual discrimination, sexual exploitation, and oppression [19]. The main principles, namely: women have the right to contribute in all aspects of the world; must be free from oppression, maximize their potential, and feminism must be able to carry out social transformation [20].

To understand the perspective of feminism towards the Merariq Kodeq phenomenon, it is also necessary to understand the view of feminism in marriage. Carole Pateman views marriage from the social contracts perspective of that lead to male domination of women and gives men the right to enjoy equal sexual access with women. This is a problem, especially in patriarchal societies, where marriage and women's loyalty are requirements for heterosexual relations. Marriage denies women's access to sexual freedom and continues to separate women from one another. In short, marriage is considered an 'intimate colonization' [21].

Meanwhile, in another feminism perspective, marriage is not a problem when it is not a forced marriage. It is important to clarify the difference between arranged and forced marriages. In arranged marriages, the two people involved are encouraged to meet with each other in the companion's timeframe or are not assisted to find out if they are suitable marriage partners. Conversely, the practice of forced marriage does not provide such opportunities and is carried out without the full agreement of the two people who are going to get married. Both men and women can be victims of forced marriages [22].

Merariq is actually one form of marriage in the Lombok Sasak tribe, which includes merariq (elopement), memagah (forced elopement), surrender of law, marriage of tadong 
(marriage of children who are hung / postponed), and melakoq (asking permission) [9]. Culture draws itself in the views of $\mathrm{O}^{\prime} \mathrm{Neil}$ and Helms who put forward the concept of gender role conflict, assuming that conditions where gender roles can influence or negatively impact a person or others. Drawing or kidnapping girls is a form of patriarchy. In merariq, men are considered authoritative and superior when marrying women by abducting from their parents or by drawing them traditionally. While the inferiority of women will indirectly choose to marry without any other choice, if there is no marriage will get a bad view from the community [23].

In its development, merariq is mostly done by children under the age of 18 years. Merariq which is done at an early age is known as Merariq Kodeq. One of the reasons Merariq Kodeq is based on like fellows. Merariq steps are taken to force parents to give their blessing of marry their children. when it cancel a marriage, it will viewed negatively by the community [24]. The Merariq tradition later contributed to a large number of child marriages in West Nusa Tenggara, reaching 4.5 percent of married children aged 15 years, and 44 percent aged under 19 years [7]. Other factors that cause merariq Kodeq are low education, economic needs, free sex in adolescents, pregnancy without marital status, young marriage culture, and arranged marriages [25].

It has triggered a reaction from the view of feminism based on its assumptions that promote human rights is regulated in The Act No.23 year 2002 on child protection and The Act No. 39 year 1999 on Human Rights, that Merariq Kodeq happened on the Lombok island, West Nusa Tenggara threaten the rights of children in accordance with the UN Convention on the Rights of the Child states that whoever the child is, where he comes from, his religion, his physical condition and disability have the same rights and the same protection as other children. Children's rights, are the right to life, growth and development, protection, and participation. [26].

The impact of child marriage is harm for women, especially for the growth and development of children and includes human rights violations that should be ended for the future. Child marriage makes the child more isolated and helpless after marriage and feels deprived of basic rights such as education, health, and protection. Emotionally they are not ready, so that domestic violence often occurs. Meanwhile, in terms of health, these children are not ready to carry a very high risk that can endanger themselves and their children, sexual health is also dangerous for children because of the higher risk of contracting HIV and other infectious diseases. As a consequence of children born from marriage, children under 19 years of age 60 percent die, are unhealthy, and become poor [2], [27], [28]. Legal rights are also very detrimental to women and children, for example child marriages are not officially registered with the government, this has an impact on the unclear status of children born, it is difficult to get a birth certificate, difficult to get an inheritance, and if divorced women are not entitled demanding anything from her husband. In the end, women become the most disadvantaged victims.

Feminism criticism of this phenomenon strongly opposes child marriage, and even radically strongly opposes the existence of marriage because it forms patriarch which leads to oppression the women, reduces their rights as human beings, moreover the effects of child marriages are detrimental to women in all aspects, starting from the rights to obtain education because of drop out, health, and even death due to bearing the danger of pregnancy at young age.

Therefore in protecting women in marriage cases in Indonesia, the Marriage Law No. 1 of 1974 in article 7 which states that the minimum age of marriage for men aged 19 years and women 16 years. Then in 2019 was changed to the age of 19 years for men and women. Cases in NTB such as West Lombok have issued West Lombok Regent Regulation No. 30 of 2018 
concerning Prevention of Child Marriage which treats children, families, stakeholders and the community. However, this continues to happen because sanctions are not yet clear, even in the Office of Religious Affairs only sanctions for not getting a marriage card but the marriage still continues [29].

\section{CONCLUSIONS}

The view of feminism in the case of child marriage in West Nusa Tenggara strongly opposes this phenomenon, because it is not in accordance with the values and principles of feminism that give full rights to women in maximizing their potential, even feminism considers it as a form of patriarchy. The existence of child marriages severely restricts the rights of women, especially girls, because marriage makes children feel isolated from the right to education, threatened health, to death. However, it is unfortunate that child marriage in West Nusa Tenggara that has been entrenched is difficult to eliminate, despite the regulations governing it at the state and local government level, child marriage continues to occur because the people of West Nusa Tenggara strongly believe that marriage makes their life problems resolved. Merariq tradition cannot be made a scapegoat in this matter, because that is not the only factor that drives the high number of child marriages in West Nusa Tenggara. Basically, the Merariq tradition is a form of freedom for women to choose their partners initially did not support the occurrence of child marriage at all.

\section{REFERENCES}

[1] Girls Not Brides Organization, “About Child Marriage,” girlsnotbrides.org. [Online]. Available: https://www.girlsnotbrides.org/about-child-marriage/. [Accessed: 17-Nov2019].

[2] Girls Not Brides Organization, "What Is The Impact of Child Marriage," girlsnotbrides.org. [Online]. Available: https://www.girlsnotbrides.org/what-is-theimpact/. [Accessed: 17-Nov-2019].

[3] KPPPA, "Press Release : KEMENTERIAN PEMBERDAYAAN PEREMPUAN DAN PERLINDUNGAN ANAK REPUBLIK INDONESIA BERGERAK BERSAMA CEGAH PERKAWINAN ANAK," kemenpppa.go.id, 2018. [Online]. Available: https://www.kemenpppa.go.id/index.php/page/read/29/2018/bergerak-bersama-cegahperkawinan-anak. [Accessed: 17-Nov-2019].

[4] A. Kurmala, "Sekjen ASEAN: pernikahan anak ancam masa depan perempuan," antaranews.com, $2019 . \quad$ [Online]. Available: https://www.antaranews.com/berita/806042/sekjen-asean-pernikahan-anak-ancammasa-depan-perempuan. [Accessed: 17-Nov-2019].

[5] Girls Not Brides Organization, "Child Marriage in Indonesia," girlsnotbrides.org. [Online]. Available: https://www.girlsnotbrides.org/where-does-ithappen/atlas/\#/indonesia. [Accessed: 16-Nov-2019].

[6] B. L. Yi, "End child marriage 'hell' for Indonesian girls, lawmaker urges," Reuters, 2019. [Online]. Available: https://www.reuters.com/article/us-indonesia-womenmarriage/end-child-marriage-hell-for-indonesian-girls-lawmaker-urgesidUSKCN1V91BD. [Accessed: 16-Nov-2019].

[7] Radio Republik Indonesia, “Angka Pernikahan Muda NTB Masuk 10 Besar Nasional,” Radio Republik Indonesia, 2017. [Online]. Available: http://rri.co.id/post/berita/456395/daerah/angka_pernikahan_muda_ntb_masuk_10_be 
sar_nasional.html. [Accessed: 16-Nov-2019].

[8] Suara NTB, "Revisi UU Perkawinan Disahkan, NTB Optimis Tekan Pernikahan Dini," suara NTB, 2019. [Online]. Available: https://www.suarantb.com/ntb/2019/09/276693/Revisi.UU.Perkawinan.Disahkan,NTB .Optimis.Tekan.Pernikahan.Dini/. [Accessed: 16-Nov-2019].

[9] M. A. B. D. A. M. A. R. H. Daud., Adat dan Upacara Perkawinan Nusa Tenggara Barat. Mataram: Departemen Pendidikan dan Kebudayaan, 1979.

[10] B. Suresh Lal, "Child Marriage in India: Factors and Problems," Int. J. Sci. Res., vol. 4, no. June, pp. 2319-7064, 2013.

[11] S. M. M. Kamal, C. H. Hassan, G. M. Alam, and Y. Ying, "Child marriage in Bangladesh: Trends and determinants,” J. Biosoc. Sci., vol. 47, no. 1, pp. 120-139, 2015.

[12] Q. Wodon, M. C. Nguyen, and C. Tsimpo, "Child Marriage, Education, and Agency in Uganda," Fem. Econ., vol. 22, no. 1, pp. 54-79, 2016.

[13] A. A. AlAmodi, "Child marriage in Yemen," Lancet, vol. 382, no. 9909, pp. 19791980, 2013.

[14] A. J. Gage, "Association of child marriage with suicidal thoughts and attempts among adolescent girls in ethiopia,” J. Adolesc. Heal., vol. 52, no. 5, pp. 654-656, 2013.

[15] J. W. Creswell, Research Design: Qualitative, Quantitative, and Mixed Methods Approaches, 4th ed. London: SAGE, 2014.

[16] J. W. Creswell, Qualitative Inquiry and Research Design: Choosing Among Five Traditions, Second. London: SAGE, 2007.

[17] B. Winarno, Dinamika Isu-isu Global Kontemporer, 1st ed. Yogyakarta: Center of Academic Publishing Service (CAPS), 2014.

[18] A. K. Mellor, "Mary Wollstonecraft's A Vindication of the Rights of Woman and the women writers of her day," in The Cambridge Companion to Mary Wollstonecraft, C. L. Johnson, Ed. Cambridge: Cambridge University Press, 2002, p. 284.

[19] B. Hook, Feminism of For Everybody. Cambridge: South End Press, 2000.

[20] B. Ropers-Huilman, Gendered Futures in Higher Education: Critical Perspectives for Change. New York: University of New York Press, 2003.

[21] S. J. Finlay and V. Clarke, “'A Marriage of Inconvenience?' Feminist Perspectives on Marriage," Fem. Psychol., vol. 13, no. 4, pp. 415-420, 2003.

[22] R. Pande, "I arranged my own marriage": arranged marriages and post-colonial feminism,", Gender, Place Cult., vol. 22, no. 2, pp. 172-187, 2015.

[23] A. F. Aniq, "Konflik Peran Gender Pada Tradisi Merarik Di Pulau Lombok,” Annu. Int. Conf. an Islam. Stud., vol. 2, pp. 2321-2339, 2012.

[24] R. D. Putri, "Upaya Menekan Angka Perkawinan Anak: Belajar dari NTB,” Tirto, 2017. [Online]. Available: https://irto.id/upaya-menekan-angka-perkawinan-anak-belajardari-ntb-cBJQ. [Accessed: 18-Nov-2019].

[25] Badan Kependudukan dan Keluarga Berencana Nasional, "Mencegah Pernikahan Anak Melalui Program KKBPK," Jakarta, 2018.

[26] UNICEF, "UN Convention on the Rights of the Child," New York, 2012.

[27] Equality Now, "What Are the Long Term Impacts of Child Marriage? Your Questions Answered," Equality Now, 2019. [Online]. Available: https://www.equalitynow.org/long_term_impacts_child_marriage. [Accessed: 18-Nov2019].

[28] International Women's Health Coalition, “The Facts on Child Marriage,” International Women's Health Coalition, 2014. [Online]. Available: https://iwhc.org/wp- 
content/uploads/2014/05/iwhc-child-marriage-facts.pdf. [Accessed: 18-Nov-2019].

[29] B.W. Setyawan and K. Saddhono, "Eret traditional ceremony as representation of spirit of mutual cooperation among coastal communities". Adv. Sci. Let. vol. 23 no.10, pp 9991-9992, 2017 